\title{
Teachers' writing proficiency and assessment ability: the missing link in teachers' written corrective feedback practice in an Iranian EFL context
}

\author{
Majid Nemati, Sayyed Mohammad Alavi, Hassan Mohebbi id and Ali Panahi Masjedlou
}

\section{* Correspondence:}

hassanmohebbi@ut.ac.ir;

hassan.mohebbi973@gmail.com Faculty of Foreign Languages and Literatures, University of Tehran, Tehran, Iran

\begin{abstract}
Background: Teachers' writing proficiency and writing assessment ability and their role in improving writing instruction in second language learning classrooms are issues that have not been investigated empirically and rigorously. To bridge the gap, we investigated the writing proficiency, writing assessment ability, and written corrective feedback beliefs and practices of Iranian English teachers who gave feedback on learners' writings.

Methods: To this end, 103 Iranian teachers who had the experience of writing instruction and assessment in their classrooms completed two writing tasks, assessed and gave feedback on two writing tasks, and responded to a researcher-made questionnaire inspecting their feedback beliefs and practices and research interest.

Results: The data analysis showed that the teachers' writing proficiency did not satisfy the expectations and standards. Their writing assessment ability was also not accurate. Moreover, the data obtained from the questionnaire indicated that the teachers mostly gave unfocused direct written corrective feedback; they did not use technology in writing instruction; and most of them did not ask the learners to revise the texts which received feedback. Furthermore, the results showed that a majority of the teachers did not study the research papers because they did not have time and lacked access to the journals.
\end{abstract}

Conclusions: As the findings of this study showed, more research is needed to improve the quality of writing instruction in Iranian classroom context. More research seems necessary especially in different contexts to come up with practical suggestions for teachers who give WCF on their students' writing and assess and grade writing. These are critical issues that merit investigation in future research.

Keywords: Written corrective feedback (WCF), Teachers' writing proficiency, Teachers' writing assessment ability, Teachers' beliefs and practices

\section{Background}

Written corrective feedback (WCF), one of the most debated issues, is heavily researched in second language (L2) writing literature. On the one hand, Truscott (1996, 1999, 2001, 2004, 2007, 2009, 2010) has openly questioned the effectiveness of WCF in L2 writing. He argues that WCF should have no place in L2 writing classes. In

(c) The Author(s). 2017 Open Access This article is distributed under the terms of the Creative Commons Attribution 4.0 International License (http://creativecommons.org/licenses/by/4.0/), which permits unrestricted use, distribution, and reproduction in any medium, provided you give appropriate credit to the original author(s) and the source, provide a link to the Creative Commons license, and indicate if changes were made. 
response to Truscott, Ferris and other researchers (e.g., Bitchener 2008, 2012a, 2012b; Chandler 2003; Ferris 1995, 1997, 1999, 2002, 2003, 2004, 2010, 2012, 2014, 2015) have provided evidence for the positive effect of WCF on improving L2 writing.

In a meta-analytical research, Kang and Han (2015) concluded that using WCF can lead to greater grammatical accuracy in L2 writing, but its positive role is mediated by different factors such as learners' proficiency, the context, and the genre of writing.

Lee (2013) classified the research findings in WCF: Research findings that have not been well applied such as amount of feedback, choice of WCF strategies, which errors should be corrected, and student uptake; research findings that have been reasonably well applied including need to act upon WCF and timely WCF; and research findings that have been over-applied.

Also, the deficiencies in the design of the studies make the findings inconclusive and not comparable. Moreover, there are some aspects of WCF that are under-researched or not researched. Some of these issues are teachers' writing proficiencies, their WCF practice, and teachers' writing assessment abilities. To date, the researchers have not included these issues in their research and the arguments for or against WCF effectiveness. This study inquires into the role of teacher's proficiency in WCF, their writing assessment ability, and their WCF beliefs and practices.

\section{WCF: teachers' proficiency}

The attempts to improve the quality of language instruction have placed greater demands on teacher language proficiency (Canh and Renandya 2017). L2 teachers' language proficiency can play a key role in L2 teaching and learning quality. This issue is of primary importance in English as a Foreign Language (EFL) context, especially in an Asian context, where the non-native speakers' (NNS) L2 proficiency is questioned (Nakata 2010; Tsang 2017). There seems to be a possible causal relationship between teacher's language proficiency and the quality of teaching and learning which takes place in L2 classrooms (Chambless 2012). Traditionally, it is assumed that higher level of teacher language proficiency results in a better quality of teaching (Richards 2017). Recently, some researchers stressed again that English language teachers require an advanced level of language proficiency to succeed in teaching (e.g., Canh and Renandya 2017; Faez and Karas 2017). In fact, teachers' proficiency, motivation, and identity may affect what students learn in L2 classroom (Valmori and De Costa 2016).

Teachers' skills and expertise in teaching writing and WCF practice play an important role in the path of a teacher's professional life (Lee 2014a, 2016). Writing is a skill which is often ignored in L2 classrooms because teachers lack adequate training in writing instruction and assessment (Dempsey et al. 2009). As Hyland (2013) rightly mentions "teacher feedback should play an important role in scaffolding cognitive development, alerting students to their strengths and weaknesses, and contributing to their acquisition of disciplinary subject matter and writing conventions" (p. 240). Therefore, a teacher who lacks the expected and standard writing proficiency will not be able to help a learner to improve his/her writing and the teacher's WCF might be misleading. Teachers who have little or no training regarding WCF strategies may face a lot of problems in correcting L2 learners' writings (Shin 2006). 
Surprisingly, one issue which is under-researched is teachers' writing proficiency. Only one study (Denny 2011), to our best knowledge, investigated the role of teachers' writing proficiency in their WCF practices and its potential effect on improving L2 learners' writing. Denny investigated the writing proficiency of 15 Anglophone Caribbean teachers of English. Interestingly, the teachers failed in the writing task based on the university's grading system. Based on these findings, Denny recommended that a writing teacher should become involved in writing research to get familiar with the research findings and the recommended principles for practicing in writing classrooms.

In a recent research study, Marefat and Heydari (2016) studied native and Iranian teachers' perceptions when assess Iranian students' English essays. One hundred fortyfour native English speakers and Iranian teachers ranked four writing criteria, namely content, organization, vocabulary, and grammar in terms of difficulty and importance. Twenty four of the participants rated eight essays written by Iranian undergraduate students. The results indicated that Iranian raters were stricter than their native English speaker counterparts in rating the essays and that there were also significant differences between these two groups in their perceptions of the difficulty and importance of organization and grammar.

Lee (2003) reported a study investigating L2 writing teachers' WCF perspectives and practices in Hong Kong's context. The result of the data obtained from questionnaire and follow-up interviews indicated that most of the teachers employed unfocused or comprehensive WCF. The teachers considered WCF as a job without any significant long-term effect and significance which has no or a little effect on improving students' writing. The findings showed that the teachers' WCF practices were not consistent with their beliefs or published research and that the teachers were not well equipped or prepared to help learners to develop self-editing strategies and skills. Montgomery and Baker (2007) reached the same conclusion observing that there was a significant difference between teachers' WCF practices and their beliefs and perceptions. They called for more research examining teachers' WCF self-assessment. In another study, Lee (2008) concluded that teachers' WCF practices are mediated by contextual factors, namely teachers' beliefs, values, knowledge, cultural, and institutional variables such as WCF philosophies and socio-cultural factors such as teacher autonomy.

Crusan et al. (2016), in a study of writing assessment literacy which considered the knowledge, beliefs, and practices of 702 writing teachers, found that a quarter of the teachers had little or no training to teach and assess writing. Also, there was a significant difference among teachers in terms of linguistic background and teacher experience.

As the literature shows, the findings of the studies are not conclusive. We need more research on teachers' writing proficiency and its effect on their classroom practice. To have a more comprehensive picture of teachers' WCF practice, we need to consider other factors such as teachers' WCF philosophies and practice and learners' needs and preferences.

\section{WCF: teacher philosophies, practice, and learner preferences}

Strikingly enough, to date, there are only a few studies that have investigated L2 teachers' WCF beliefs in L2 learning classroom contexts. Ferris (2014) rightly stresses that “The teachers' voices have been the missing link in the research base 
to date" (p. 6) while teachers' practices in classroom context are considerably influenced by teachers' personal beliefs and theories (Borg 2003).

Ferris (2014) employed a mixed-methods approach to examine the teachers' philosophies and practices when they respond to student writing by surveying and interviewing community college and university writing teachers. The findings revealed different practices and viewpoints among teachers. Moreover, the data analysis showed that although in many ways the teachers' observed practices were in line with what they have expressed on the survey, there were some inconsistencies between teachers' selfreported responses and their practices. In sum, she concluded that teachers need to evaluate their own WCF strategies and practices and make the necessary adjustments.

Amrhein and Nassaji (2010) investigated the L2 teachers' and learners' viewpoints about the implementation of WCF. The data obtained through the questionnaire revealed that the students and teachers were of the same opinions about the positive effect of focused WCF and direct WCF. The learners expressed that they preferred direct WCF coupled with a metalinguistic explanation. In this case, the learners shunned the responsibility of peer WCF and indirect WCF that is in marked contrast with the goal of L2 learning pedagogy which aims at helping learners to reach autonomy. Additionally, the learners preferred WCF on form-focused errors like grammatical and lexical errors.

Lee (2009) studied teachers' beliefs about WCF in L2 pedagogy, and their practice in L2 learning classroom through analyzing the texts that were given WCF by the teachers, follow-up interviews with them, and a questionnaire. She observed ten mismatches between the teachers' beliefs about WCF implementation and their practice in L2 learning. More importantly, the observed teachers paid the most attention to language form while they believed that accuracy is not the only factor which enhances the quality of a manuscript. Teachers provided unfocused WCF while they believed that focused WCF is more effective. Although they provided WCF, they were in favor of peer WCF. While they gave indirect WCF, they thought that the learners were not able to take advantage of the indirect WCF and correct the errors. They expressed that grading is not an effective strategy, but they kept on grading anyway. The teachers focused mainly on weak points in giving WCF while they expressed that an effective WCF needs to cover both weak points and strong points in the learners' writing.

The findings of the study conducted by Zhou et al. (2014) demonstrated that there was no correspondence between students' and teachers' goals for grammar improvement in writing. The participants in McMartin-Miller's (2014) study expressed preference for unfocused WCF; however, they were satisfied with their teacher's focused WCF strategy. She concluded that teachers need to ensure that the students are fully aware of the teacher's WCF strategy, i.e., how and why errors are treated.

Lee (2008) observed that teachers continue to practice unfocused WCF despite the research findings which indicate their lack of training and not being up-to-date with the recent research findings. As the literature indicated, there is a gap in L2 literature inquiring into L2 teachers' and learners' beliefs and practices in L2 writing instruction. To fill the gap in L2 literature in this field, this study probes into teachers' WCF practices based on learners' perceptions. Additionally, this research aims to study learners' preferences with regard to implementing WCF in an EFL context. Furthermore, teachers are interviewed about their WCF strategies and the philosophy behind their WCF strategies. 
Lee's findings are supported by numerous studies. For example, Li and Barnard (2011) reported a New Zealand university case study examining the beliefs and practices of untrained and inexperienced tutors about giving WCF on students' assignments. They observed that the tutors' main reason behind their WCF strategy was not to improve the students' writing skill but to justify the awarded grades.

In another study of a novice teacher's WCF beliefs and practices, Junqueira and Payant (2015) observed that, although the teacher believed in giving WCF on global concerns, in practice, he provided WCF on local issues most of the time. Focus is another issue. Jodaie and Farrokhi (2012) found that $60 \%$ of 30 English teachers in an Iranian classroom context were in favor of unfocused or comprehensive WCF. By contrast, Lee et al. (2016) explored the attempts made by two secondary teachers in Hong Kong to promote WCF innovation. Surprisingly, the teachers were not able to employ effectively the WCF principles they have learnt from teacher education.

Mahfoodh's (2017) investigation of students' emotional responses toward teachers' WCF practices revealed that the students felt frustrated after receiving unfocused WCF on their writing. The students' reactions toward their teachers' WCF were classified into accepting WCF, rejecting WCF, surprise, happiness, dissatisfaction, disappointment, frustration, and satisfaction. He attributed some of the students' emotional reaction to miscommunication between teachers and students.

In a more recent research study, Nemati et al. (2017) studied 311 elementary, intermediate, and upper-intermediate and advanced language learners' perceptions, beliefs, and preferences about teachers' feedback practice in Iranian classrooms. The results showed some similarities and differences across the three proficiency levels. They all were in favor of direct unfocused WCF. However, they had different viewpoints on the satisfaction with their teachers' WCF strategy and practice; need to revise their writing after receiving teacher's WCF; the targeted structures on which teachers should give WCF; and their feeling after receiving WCF. The findings also indicated some discrepancies between research findings, teacher's WCF practice, and learners' preferences.

\section{Expanding the boundary of WCF research}

To date, L2 researchers have investigated different aspects of the effect of WCF on improving writing accuracy of L2 learners. However, despite the growing amount of research on WCF, there are a lot of aspects which have gone unnoticed, under-researched, or not researched. Chandler (2003) rightly underscores the fact that the existing data are not conclusive. The result of the methodological synthesis of research conducted by Liu and Brown (2015) revealed the need for more robust research. Similarly, Ferris (2010) highlighted the wide gap among research, theory, and real-world WCF practice.

Evans et al. (2010) suggested that we need to consider learner, situational, and methodological variables in doing research to be able to close the perceived gap. Figure 1 exhibits the contributing variables.

As Ferris (2014) rightly asserts, "only rarely have teachers themselves been utilized as primary informants in studies on response" (p. 6). She highlights the gap in the literature regarding studying teachers' viewpoints and practices, i.e., what they do and why they do it. Lee (2003) expressed dissatisfaction with the amount of research on teachers' WCF beliefs and perceptions. As Lee (2013) underscores: "very little is known about 
WCF

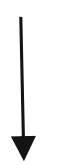

\section{Learner Variables}

- Motivation

- Learning style

- Goals

- L1

\section{Situational Variables}

- Teacher

- Physical environment

- Socioeconomic conditions

Methodological Variables

- Instructional design

- What is taught

- How it is taught

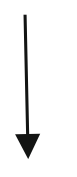

\section{L2 writing accuracy}

Fig. 1 Contextual factors in L2 writing influencing learning and research 
what actually happens in the classroom when teachers respond to errors in student writing" (p. 108). Therefore, we need more research to bridge this gap in L2 writing and WCF research.

\section{The study}

This study investigates teachers' writing proficiency and teachers' WCF practices in an Iranian context. Taken together, this study is an attempt to fill the gaps in the literature regarding teachers' writing proficiency, their WCF knowledge, beliefs, and practices in an EFL classroom context. The potential role of teachers' WCF pedagogical knowledge and abilities and also their beliefs and practices remain under-investigated and so deserving more attention. Evidently, research assessing and quantifying teachers' writing assessment ability is surprisingly rare (Crusan et al. 2016).

\section{Research questions}

Based on the reviewed literature, this study investigates the following research questions:

$\mathrm{RQ}_{1}$ : What is the writing proficiency level of Iranian EFL teachers who give WCF on their students' writing?

$\mathrm{RQ}_{2}$ : What is the writing assessment ability of Iranian EFL teachers who give WCF on their students' writing?

$\mathrm{RQ}_{3}$ : What are the WCF beliefs and practices of Iranian EFL teachers who give WCF on their students' writing?

\section{Methods}

\section{Context, participants, and procedures}

The participant population was limited to Iranian English language teachers in English language institutes who assign, assess, and grade writing tasks and give WCF. To this end, we issued a call to participate in this research project. We sent a letter of invitation to institutes, emailed teachers, and announced the research project in social media channels such as Telegram and LinkedIn. Although more than 250 persons volunteered to participate in the study, only 103 teachers completed all the tasks. The teachers completed two writing tasks, assessed two samples of writing and gave WCF on the samples, and responded to a questionnaire.

Six of the teachers had Associate of Arts, 48 held Bachelor of Arts, 47 had Master of Arts, and only 2 were $\mathrm{PhD}$ candidates. With the exception of two of the teachers who had studied computer engineering and one who had studied Persian Literature, all of the teachers had studied Teaching English as a Foreign Language, English Translation Studies, and English Literature. The teachers' age ranged from 20 to 38. Sixty-eight of the teachers were female, and 35 of them were male. More than $90 \%$ of their students were teenagers and young adults. Eighty-two percent of the teachers had been teaching in pre-intermediate, intermediate, and upper-intermediate levels of English proficiency classes. Only $18 \%$ of the participants had also been teaching in advanced classes. More than $60 \%$ of the teachers had at least 4 years of teaching experience; almost $25 \%$ of them had 6-10 years of teaching experience. All of them had experience in and a background of teaching and grading writing in their classes. However, there was a 
significant discrepancy in the number of times each teacher assessed and gave WCF on learners' writings. The frequency was between 4 and 16 times in which teachers gave WCF on students' writings which can be attributed to different institutes' curriculum and teachers' practice. Table 1 presents the demographic data of the teachers.

Instruments ${ }^{1}$

Teachers' writing task

To assess the writing proficiency of the teachers, two writing tasks were adopted from Cambridge IELTS 11 (General Module) which includes authentic International English Language Testing System (IELTS) exam papers. The first writing task required the teachers to write a letter of at least 150 words in $20 \mathrm{~min}$. The second writing task was an essay writing with a minimum of 250 words written in $40 \mathrm{~min}$. In selecting these types of writing tasks, we followed Coniam and Falvey's (2013) Hong Kong language proficiency assessment for teachers of English (LPATE) and Arizona's Spanish proficiency test for bilingual teachers (Grant 1997). The reason for choosing IELTS letter and essay writing tasks was that these tests can be considered as valid measures of assessing writing proficiency. The writings were assessed by one of the authors. To ensure the reliability of the assessment, almost $25 \%$ of each writing tasks was rated again by another researcher. The Pearson correlation coefficient inter-rater reliability was nearly .96 .

\section{Teachers' writing assessment and WCF strategy task}

To assess teachers' writing assessment ability and their WCF strategies, we designed a task. Teachers were required to assess two writing pieces, giving a score based on the IELTS writing assessment criteria. We provided the IELTS band descriptors as an appendix to all teachers. The writing samples provided by two examinees in the two writing tasks which teachers in the first stage of the study had completed were adopted from Cambridge IELTS 11 (General Module), a letter writing and an essay writing tasks. The samples adopted had been assessed by the IELTS examiners and the scores of 4.5 and 6.5 were given to the letter and essay writing tasks, respectively.

Table 1 Demographic data of teachers

\begin{tabular}{ll}
\hline Number of teachers & 103 \\
\hline Female & 68 \\
Male & 35 \\
Age range & $20-38$ \\
Degree & Associate of arts $=6$ \\
& Bachelor of arts $=48$ \\
& Master of arts $=47$ \\
Major & PhD $=2$ \\
& TEFL/translation studies/English literature $=100$ \\
& Computer engineering $=2$ \\
Teaching experience & Persian literature $=1$ \\
& $60 \%=4$ years \\
& $25 \%=6-10$ years \\
& $15 \%=$ less than 4 years \\
\hline
\end{tabular}




\section{Teachers' WCF beliefs and perceptions questionnaire}

To inquire into teachers' WCF beliefs and perceptions, we used a questionnaire incorporating the instruments developed in Ferris (2014), Marefat and Heydari (2016), McMartin-Miller (2014), Lee (2003), Lee (2008, 2009), Montgomery and Baker (2007), Junqueira and Payant (2015), Valmori and De Costa (2016), Nassaji (2012), Tavakoli and Howard (2012), Tavakoli (2015), and Crusan et al. (2016). Also, we used the WCF typologies suggested by Ellis (2009). We conducted a pilot study and revised the questionnaire based on some researchers' and teachers' suggestions. The questionnaire had seven sections. The first section provided biodata about the teachers' age, education, and teaching experience. In the second section, there were 12 statements about teachers' WCF practice in their classroom in a Likert-type scale. The teachers needed to read each statement and choose: always, sometimes, or never. The third section included the target structures and forms for which teachers give WCF. The teachers were required to select the frequency with which they gave WCF on these structures. The fourth section asked teachers whether they mention the positive points in their learners' writings or not and what is the most difficult and the most important targeted form or structure in assessing or grading writing. Section six inquired into teachers' research background and interests, their familiarity with the journals in writing, the role of reading research in their WCF and writing instruction and assessment practice, and the courses in writing instruction and assessment they have undertaken. The last section of the questionnaire asked teachers how they improve their proficiency, especially writing skill.

The data obtained from the three instruments were analyzed. The following section elaborates the results of data analysis.

\section{Results and discussion}

\section{Teachers' IELTS letter and essay writing tasks}

The data analysis showed that the teachers scored 4.5 in IELTS letter writing task on average $(M=4.43, \mathrm{SD}=.94)$. Table 2 and Fig. 1 present the descriptive statistics (Fig. 2).

The teacher's mean score in IELTS essay writing task was similar to their score in IELTS letter writing task $(M=4.68, \mathrm{SD}=1.03)$. Table 3 and Fig. 3 depict the results in detail.

\section{Teachers' writing assessment tasks and WCF strategy}

The teachers were asked to assess and grade a letter and an essay writing tasks which had been taken from the Cambridge IELTS 11 book. The samples were assessed by the official IELTS assessors and were given 4.5 and 6.5 for the letter and essay tasks, respectively. To assess the teachers' assessment ability, we asked the teachers to assess and give scores to the samples based on IELTS writing assessment band descriptors given. The data analysis showed that the teachers gave almost 6 to the letter writing task which was given 4.5 by IELTS official assessors. Table 4 and Fig. 4 represent the data analysis clearly. Of note was that the minimum and maximum scores were 3 and 8 .

Table 2 Descriptive statistics of teachers' letter writing task scores

\begin{tabular}{llllll}
\hline$N$ & Minimum & Maximum & Mean & SD & Variance \\
\hline 103 & 3.00 & 7.50 & 4.43 & .94 & .88 \\
\hline
\end{tabular}




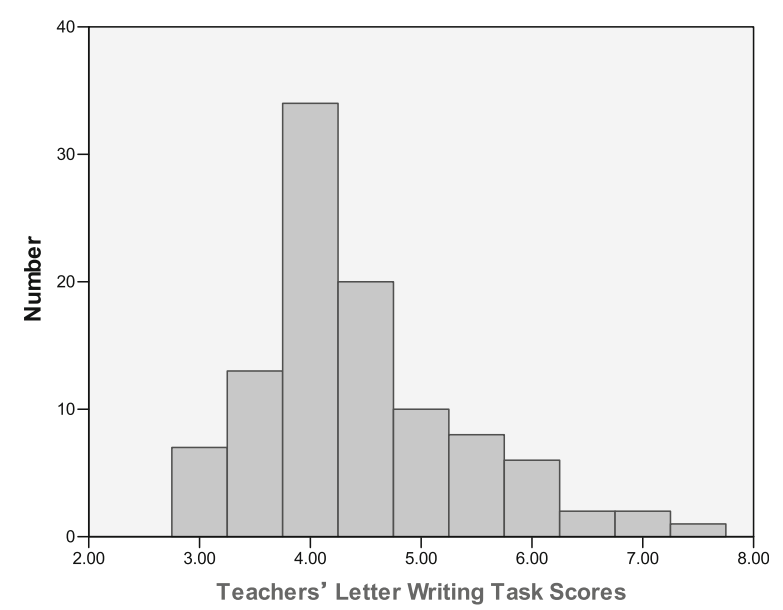

Fig. 2 Teachers' letter writing task scores

The data analysis of the sample IELTS essay writing task indicated that the teachers gave almost 5.5 to the essay writing task which was given 6.5 by IELTS official assessors. Table 5 and Fig. 5 show the results. Surprisingly, the minimum and maximum scores were 3 and 8.5 for the writing which received 6.5 .

The teachers were also required to give feedback on the sample IELTS letter and writing tasks. The data obtained were disappointing due to the fact that roughly onethird of the teachers did not give comprehensive WCF on the writings. The majority of the WCF were on mechanics. Regarding the target structure of the WCF, the teachers mainly corrected errors of articles and tenses. There was no WCF on the content and organization. Despite the teachers' self-report claiming that they mention the positive points of the writing, there were only two cases in which teachers praised the positive points in the writings. Regrettably, there were some traces of incorrect WCF given by the teachers. For example, they have mistakenly changed a correct sentence to an incorrect one.

\section{Teachers' WCF strategies, beliefs, and practices}

The first part of the questionnaire was about teachers' background and metadata which were explained above in the participant's section.

The second part of the questionnaire was about teachers' WCF strategies. The first section of this part was devoted to teachers' WCF strategies and practice in their classrooms. The data analysis revealed that a majority of the teachers employed unfocused direct WCF. They sometimes gave metalinguistic explanations either in Persian or English. Almost none of them used the Internet nor software about writing and correction or grammar in giving WCF. Approximately, half of the teachers used peer WCF only sometimes by asking the peers about correct usage when giving WCF on their

Table 3 Descriptive statistics of teachers' essay writing task scores

\begin{tabular}{llllll}
\hline$N$ & Minimum & Maximum & Mean & SD & Variance \\
\hline 103 & 3.00 & 7.50 & 4.68 & 1.03 & 1.07 \\
\hline
\end{tabular}




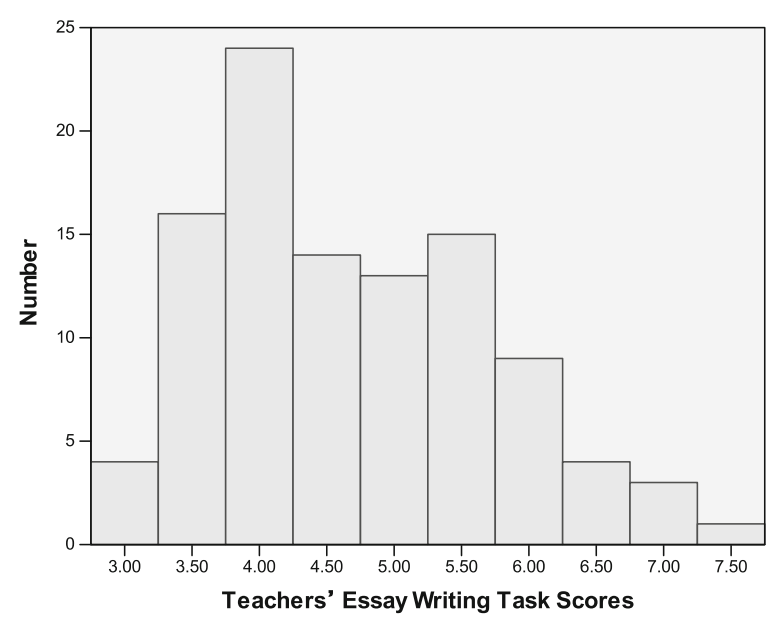

Fig. 3 Teachers' essay writing task scores

classmate's writing. More than $70 \%$ of the teachers responded that they did not ask the learners to revise their writing based on the WCF given either by teacher or peer.

\section{Target structures}

The teachers were asked to rank the structure for which they gave WCF. The data obtained indicated that they mostly gave WCF on errors attributed to tenses, voice, modals, and definite and indefinite articles. The least level of WCF was the content and organization of the learners' writing.

\section{Appraisal}

More than $90 \%$ of the participating teachers stated that they appraised the learners and mentioned the positive points of learners' writings. However, there was little trace of appraisal in the samples corrected by the teachers. This was one of the observed mismatches between teachers' claim and their practice.

\section{The most difficult and important parts}

The teachers also mentioned that the organization of writing is the most difficult aspect in correcting learners' writing. They also expressed that grammar and organization are the most important aspects which teachers should give WCF on learners' writing.

\section{Research interest and engagement}

Surprisingly enough, almost $60 \%$ of the teachers were not familiar with the journals in the field of second language writing; accordingly, they did not study the journals publishing research papers on writing instruction and WCF. Their main reasons for not studying research papers were not having time to study and not having access to the journals. Also, a quarter of the teachers stated that the language of the research papers published in the

Table 4 Descriptive statistics of teachers' assessment of sample letter writing task

\begin{tabular}{llllll}
\hline$N$ & Minimum & Maximum & Mean & SD & Variance \\
\hline 103 & 3.00 & 8.00 & 5.83 & 1.24 & 1.55 \\
\hline
\end{tabular}




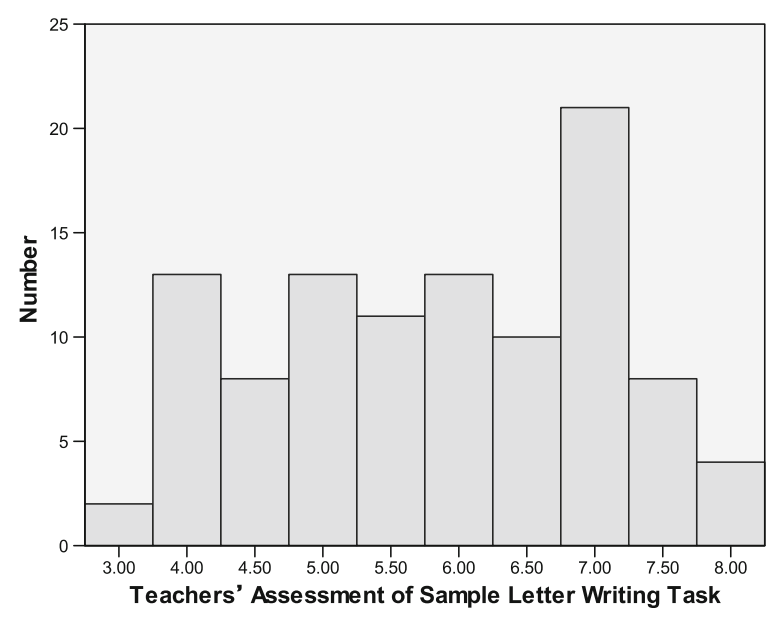

Fig. 4 Teachers' assessment of sample letter writing task

journals is too technical and that they cannot understand and practice the research findings. Approximately, $90 \%$ of the teachers had never taken any course in teaching and assessing writing. They mentioned that the institutes in which they worked did not hold any in-service and on-the-job training courses, particularly writing courses.

\section{English proficiency}

Part 4 of the questionnaire included three open-ended questions regarding how teachers maintain and upgrade their proficiency. The results show that the teachers studied textbooks to keep their language proficiency. A majority of them expressed that they did not do anything special to improve their writing proficiency. They asserted that they just read graded short stories, novels, and books on teaching methods to develop their English proficiency and upgrade their teaching knowledge.

WCF has been one of the controversial issues in L2 teaching literature. There are still some issues that are untouched or under-researched yet. Teacher's writing proficiency and writing assessment ability and their role in improving writing instruction and learners' writing have not been investigated empirically and rigorously. Similarly, teachers' WCF beliefs and practices have yet to be researched extensively. To bridge the perceived gap in the literature, we investigated the writing proficiency, writing assessment ability, and WCF beliefs and practice of Iranian English language teachers who gave WCF on learners' writing.

Regarding the first research question, the data analysis showed that the mean score of the teachers who completed two IELTS letter writing and essay writing tasks was almost 4.50 out of a possible 9 . Although we should analyze the data cautiously due to the sample size, the results of the teachers' writing proficiencies can serve as a strong warning. When a teacher is not able to write accurately, he or she cannot help learners improve their writing proficiency. Teachers' own language proficiency may influence

Table 5 Descriptive statistics of teachers' assessment of sample essay writing task

\begin{tabular}{llllll}
\hline$N$ & Minimum & Maximum & Mean & SD & Variance \\
\hline 103 & 3.00 & 8.50 & 5.45 & 1.34 & 1.79
\end{tabular}




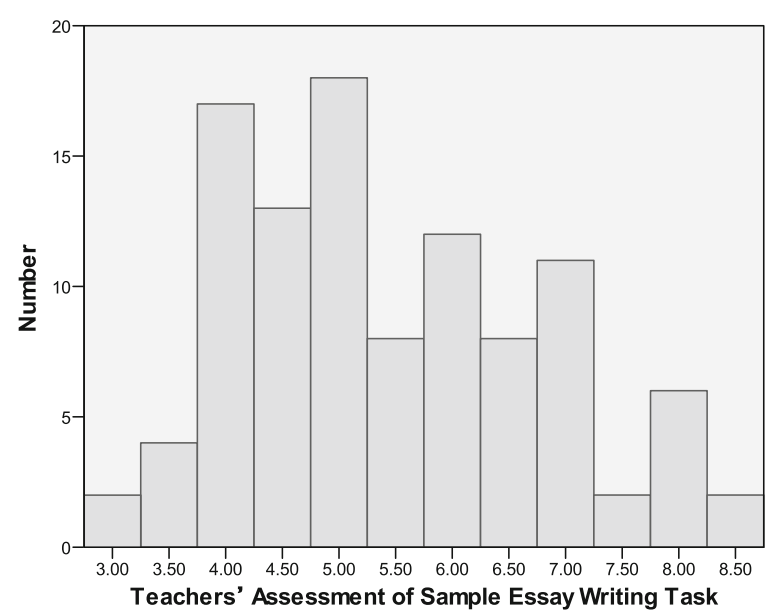

Fig. 5 Teachers' assessment of sample essay writing task

what students learn. As already discussed, teachers' proficiency may have a direct effect on teaching and learning. As expressed by one of the teachers, writing is the skill which has been given scant attention in the Iranian English classroom context. Moreover, as seems evident, writing courses and teaching and assessing writing courses do not occupy an important place in BA and MA programs and teacher training and teacher education courses in Iran.

Regrettably, there is no established governmental or national policy on English instruction in Iran. Although there is a curriculum for teaching English in public schools, this curriculum does not meet learners' needs in terms of the English language proficiency needed at the international level. While there are thousands of English language private schools, there are no comprehensive plans in institutes. More importantly, the teacher training and teacher education courses do not satisfy teachers' needs. Clearly, teaching writing skills does not have its rightful and important place in English teaching curriculum in the Iranian context. It should be mentioned that this status is rooted in the philosophy behind the language teacher training courses which focus exclusively on general language fluency and do not address teachers' professional and pedagogical needs (Freeman 2017). We need to provide writing teaching and assessment courses for teachers to attain a high level of proficiency to meet learners' language needs.

Regarding the second research question, the participating teachers' writing assessment ability was concerning too because their grading was not accurate. As the data from the questionnaire revealed, the teachers were not familiar with the journals in the field of second language writing. Consequently, they do not keep abreast of current developments in second language teaching. They also expressed dissatisfaction with having no access to the journals and not having the chance to attend writing instruction and assessment courses. Given that a majority of the teachers had no broad background and expertise in teaching and assessing writing, the result of the teachers' writing assessment should come as no surprise. Therefore, we should offer writing assessment courses for teachers to improve their writing assessment literacy. 
Regarding the third research question, as the data indicated, the teachers could not give comprehensive WCF on the writing samples. Moreover, the data indicated that the teachers mostly gave unfocused direct WCF, they did not use any software or technology in writing instruction, and most of them did not ask the learners to revise the texts which received WCF. Finally, they mentioned that they read only graded short stories, novels, and teaching methods to develop their English and teaching proficiency. Unfortunately, some of the teachers gave incorrect feedback which may be harmful for learners. Furthermore, most of the teachers' WCF was on mechanics while the learners need feedback on other aspects of writing too. Each of these issues needs more research because these findings are in contrast with the research findings. More research is needed to investigate why Iranian teachers are not willing to use other types of WCF, why they hardly use technology in their writing teaching, and more importantly, why they do not ask their students to revise their writing after receiving teacher's WCF. It seems that these issues would be due to lack of teachers' expertise and gaps in their pedagogical knowledge. However, we need more mixed methods and longitudinal research to support the findings of this study. Furthermore, we need to use other research instruments such as observation and interviews with teachers to triangulate the data.

In brief, the findings revealed that the teachers did not have the writing proficiency and writing assessment ability that they needed. Also, their WCF practice was not in line with the research findings. Most of the teachers did not ask for revisions while the research findings underscore the positive effect of revision on improving learners' writings. They did not use technology and software in teaching writing and giving WCF. These issues should be researched thoroughly to reach a conclusion and try to change teachers' WCF practice.

Surprisingly, the teachers did not practice peer WCF despite the research findings indicating the significant impact of it on helping learners to write more accurately. As Lee (2013) underscored, WCF is an area of L2 research where serious mismatches exist between researchers' research findings and teachers' classroom applications. Lee (2013) sums up that

In the end, it is not WCF researchers who mark student writing, but classroom teachers. Thus, we need to help teachers generate practical and practitioner knowledge and empower them through classroom-based research, so that they figure out their own effective ways to give feedback without necessarily transferring findings from previous research that is conducted in dissimilar contexts, or in laboratory-like conditions that are remote from classroom realities. (p. 117)

To implement effective writing classes and give efficient WCF, we agreed with Shin's (2006) recommendation that teachers and students should collaborate and come to an agreement on which WCF strategy works the best in each specific context.

Writing assessment ability is another issue which should be taken into account when discussing the quality and quantity of teachers' WCF strategies, practices, and perceptions. Unfortunately, a majority of graduate programs do not have writing assessment courses and there is only a limited time devoted to teaching writing (Weigle 2007). 
In sum, the findings of this study reveal that there are mismatches between research findings and teachers' WCF practice. Moreover, researchers should consider teacher's writing proficiency, writing assessment ability, and WCF practice in classroom in research on writing and WCF. As it seems, there are a great deal of inconsistencies and paradoxes in teachers' proficiency, assessment ability, and WCF practice which are taken for granted.

\section{Limitations, implications, and suggestions for future research}

This study has limitations inherent in small-scale research on teachers' beliefs and practices. First, because the sample is not a representative sample of all Iranian teachers, the findings should not be generalized to other contexts. The findings of this study need to be verified by further research in different contexts. Second, like all other studies, this study suffers from the problems inherit in using questionnaires. As Gu (2016) rightly warns, survey and questionnaire research is exploratory; therefore, the findings of survey studies should be treated with considerable caution. Third, as Murphy (2000) highlighted, students' voices are the missing link which restricts the conclusions to be drawn from research. Therefore, we need much more research probing into learners' voices, viewpoints, needs, and preferences to complement the findings of this study and have a much more complete picture. Future researchers are advised to use different writing tests for assessing teachers' writing proficiency which might lead to a different result.

In terms of implications, the research findings should be brought to the classrooms and practiced by teachers. Lee (2016) is not optimistic about convincing schools and teachers to initiate effective changes in their WCF practices.

Furthermore, insufficient attention has been given to the content of teacher training and teacher education programs regarding teaching and assessing writing (Hirvela and Belcher 2007); therefore, future researchers should investigate the needs of writing teachers too. As Lee (2014b) calls for, we are in need of more socioculturally based research. Future research should study teachers' WCF practices and beliefs in different contexts.

There is also a need for teacher training and teacher education courses focusing exclusively on writing instruction, WCF, and assessment. Lee (2010) mentions that the effect of teacher education programs on teachers' WCF practice in classroom warrants much more research.

Clearly, we need to prepare teachers for WCF practice, writing instruction, and assessing writing. We should incorporate WCF into teacher training programs. Teachers should be given the chance to attend conferences and workshops on WCF and writing instruction and assessment. Teachers need to have access to the journals of second language research. They should be involved in action research. Teachers, especially the newcomers, should be helped to read research papers. There is a need for researchers' and teachers' collaboration. Researchers need to get more involved in classrooms, observe teachers' practice, reflect on their practices, analyze teachers' and learners' needs, and do research to provide teachers with suggestions based on findings of studies conducted in similar classroom contexts, not in different contexts or in laboratories. 
Moreover, regarding the Iranian context, we need to establish a teacher language proficiency benchmark, design teacher proficiency tests, and also require providers of teacher training and teacher education courses to revise the content of such programs to include writing instruction and assessment.

\section{Conclusions}

Although teacher's WCF is time-consuming, it is considered a desirable and helpful strategy and practice. We need to enhance the quality of WCF practice in language learning classrooms. We hope this study triggers more research on teachers' writing proficiency and writing assessment literacy which is currently under-researched. Teachers' and learners' voices, expectations, and needs are the missing link in the field of writing research too. As Richards (2017) highlighted, future research needs to focus on the role of teacher language proficiency in shaping teachers' practice in classroom and the differential effects of teacher language proficiency on different language skills and various aspects of classroom instruction.

Finally, writing instruction and assessment should be given more attention in teacher education programs. Policy makers and program developers should pay close attention to the content of teacher training and education programs and include content related to what Freeman (2017) calls knowledge-for-teaching which is already called content knowledge or pedagogical knowledge.

In sum, as the findings of this study showed, more research is needed to improve the quality of writing instruction in Iranian classroom context. More research seems necessary especially in different contexts to come up with practical suggestions for teachers who give WCF on their students' writing. These are critical issues that merit investigation in future research.

\section{Endnote}

${ }^{1}$ The instruments used in this study are uploaded to http://www.iris-database.org/ iris/app/home/index.

\section{Acknowledgements}

We are grateful to the editor-in-chief and the anonymous reviewers for their constructive feedback on prior versions of this article. This article also benefited greatly from the helpful comments of Bernard McKenna and Hossein Vafadar. We thank the teachers who participated in the study. All shortcomings belong solely to us.

\section{Funding}

There is no funding.

\section{Authors' contributions}

MN and SMA made substantial contributions to the idea of the paper and proofread the paper. APM collected the data. HM did the data analysis and wrote the paper. All authors read and approved the final manuscript.

\section{Authors' information}

Majid Nemati is an associate professor in the Faculty of Foreign Languages and Literatures, University of Tehran, Tehran, Islamic Republic of Iran. His main research interests are form-focused instruction and corrective feedback. Sayyed Mohammad Alavi is a professor in the Faculty of Foreign Languages and Literatures, University of Tehran, Tehran, Islamic Republic of Iran. His main research interests are assessment and testing.

Hassan Mohebbi (corresponding author) is a PhD candidate in the Faculty of Foreign Languages and Literatures, University of Tehran, Tehran, Islamic Republic of Iran. His main research interests are form-focused instruction and corrective feedback.

Ali Panahi is a PhD candidate in the Faculty of Foreign Languages and Literatures, University of Tehran, Tehran, Islamic Republic of Iran. His main research interests are assessment and testing. 


\section{Publisher's Note}

Springer Nature remains neutral with regard to jurisdictional claims in published maps and institutional affiliations.

\section{Received: 13 November 2017 Accepted: 12 December 2017}

Published online: 29 December 2017

\section{References}

Amrhein, HR, \& Nassaji, H. (2010). Written corrective feedback: what do students and teachers prefer and why? Canadian Journal of Applied Linguistics, 13(2), 95-127.

Bitchener, J. (2008). Evidence in support of written corrective feedback. Journal of Second Language Writing, $17(2), 102-118$

Bitchener, J. (2012a). A reflection on 'the language learning potential' of written CF. Journal of Second Language Writing, 21(4), 348-363.

Bitchener, J. (2012b). Written corrective feedback for L2 development: current knowledge and future research. TESOL Quarterly, 46(4), 855-867.

Borg, S. (2003). Teacher cognition in language teaching: a review of research on what language teachers think, know, believe, and do. Language Teaching, 36(2), 81-109.

Canh, LV, \& Renandya, WA. (2017). Teachers' English proficiency and classroom language use: a conversation analysis study. RELC Journal, 48(1), 67-81.

Chambless, KS. (2012). Teachers' oral proficiency in the target language: research on its role in the language teaching and learning. Foreign Language Annals, 45(s1), 141-162.

Chandler, J. (2003). The efficacy of various kinds of error feedback for improvement in the accuracy and fluency of L2 student writing. Journal of Second Language Writing, 12, 267-296.

Coniam, D, \& Falvey, P. (2013). Ten years on: the Hong Kong language proficiency assessment for teachers of English (LPATE). Language Testing, 30(1), 147-155.

Crusan, D, Plakans, L, Gebril, A. (2016). Writing assessment literacy: surveying second language teachers' knowledge, beliefs, and practices. Assessing Writing, 28, 43-56.

Dempsey, MS, PytlikZillig, LM, Bruning, RH. (2009). Helping preservice teachers learn to assess writing: practice and feedback in a web-based environment. Assessing Writing, 14, 38-61.

Denny, SL. (2011). Seeing writing right and righting writing: an investigation into teacher writing proficiency. International Journal of Humanities and Social Science, 1(3), 221-234.

Ellis, R. (2009). A typology of written corrective feedback. ELT Journal, 63(2), 97-107.

Evans, NW, Hartshorn, KJ, McCollum, RM, Wolfersberger, M. (2010). Contextualizing corrective feedback in second language writing pedagogy. Language Teaching Research, 14(4), 445-463.

Faez, F, \& Karas, M. (2017). Connecting language proficiency to (self-reported) teaching ability: a review and analysis of research. RELC Journal, 48(1), 135-151.

Ferris, DR. (1995). Student reactions to teacher response in multiple-draft composition classrooms. TESOL Quarterly, 29(1), 33-53.

Ferris, DR. (1997). The influence of teacher commentary on student revision. TESOL Quarterly, 31, 315-339.

Ferris, DR. (1999). The case for grammar correction in L2 writing classes: a response to Truscott (1996). Journal of Second Language Writing, 8(1), 1-11.

Ferris, DR (2002). Treatment of error in second language student writing. Ann Arbor: The University of Michigan Press.

Ferris, DR (2003). Response to students writing: implications for second language students. Mahwah: Lawrence Erlbaum.

Ferris, DR. (2004). The "grammar correction" debate in L2 writing: where are we, and where do we go from here? (and what do we do in the meantime....?). Journal of Second Language Writing, 13, 49-62.

Ferris, DR. (2010). Second language writing research and written corrective feedback in SLA: intersections and practical applications. Studies in Second Language Acquisition, 32, 181-201.

Ferris, DR. (2012). Written corrective feedback in second language acquisition and writing studies. Language Teaching, 45(4), 446-459.

Ferris, DR. (2014). Responding to student writing: teachers' philosophies and practices. Assessing Writing, 19, 6-23.

Ferris, DR. (2015). Written corrective feedback in L2 writing: Connors \& Lunsford (1988); Lunsford \& Lunsford (2008); Lalande (1982). Language Teaching, 48(4), 531-544.

Freeman, D. (2017). The case for teachers' classroom English proficiency. RELC Journal, 48(1), 31-52.

Grant, L. (1997). Testing the language proficiency of bilingual teachers: Arizona's Spanish proficiency test. Language Testing, 14(1), 23-46.

Gu, PY. (2016). Questionnaires in language teaching research. Language Teaching Research, 20(5), 567-570.

Hirvela, A, \& Belcher, D. (2007). Writing scholars as teacher educators: exploring writing teacher education. Journal of Second Language Writing, 16, 125-128.

Hyland, K. (2013). Faculty feedback: perceptions and practices in L2 disciplinary writing. Journal of Second Language Writing, 22, 240-253

Jodaie, M \& Farrokhi, F. (2012). An exploration of private language institute teachers: perceptions of written grammar feedback in EFL classes. English Language Teaching, 5(2), 58-67.

Junqueira, L, \& Payant, C. (2015). "I just want to do it right, but it's so hard": a novice teacher's written feedback beliefs and practices. Journal of Second Language Writing, 27, 19-36.

Kang, E, \& Han, Z. (2015). The efficacy of written corrective feedback in improving L2 written accuracy: a meta-analysis. The Modern Language Journal, 99(1), 1-18.

Lee, I. (2003). L2 writing teachers' perspectives, practices and problems regarding error feedback. Assessing Writing, 8, $216-237$

Lee, I. (2008). Understanding teachers' written feedback practices in Hong Kong secondary classrooms. Journal of Second Language Writing, 17(2), 69-85.

Lee, I. (2009). Ten mismatches between teachers' beliefs and written feedback practice. ELT Journal, 63(1), 13-22. 
Lee, I. (2010). Writing teacher education and teacher learning: testimonies of four EFL teachers. Journal of Second Language Writing, 19, 143-157.

Lee, I. (2013). Research into practice: written corrective feedback. Language Teaching, 46(1), 108-119.

Lee, I. (2014a). Ten myths about teaching and learning of writing in EFL contexts. Learn Journal: Language Education and Acquisition Research Network, 7(special issue), 23-32.

Lee, I. (2014b). Revisiting teacher feedback in EFL writing from sociocultural perspectives. TESOL Quarterly, 48(1), 201-213.

Lee, I. (2016). Teacher education on feedback in EFL writing: issues, challenges, and future directions. TESOL Quarterly, 50(2), 518-527.

Lee, I, Mak, P, Burns, A. (2016). EFL teachers' attempts at feedback innovation in the writing classroom. Language Teaching Research, 20(2), 248-269.

Li, J, \& Barnard, R. (2011). Academic tutors' beliefs about and practices of giving feedback on students; written assignments: a New Zealand case study. Assessing Writing, 16, 137-148.

Liu, Q, \& Brown, D. (2015). Methodological synthesis of research on the effectiveness of corrective feedback in L2 writing. Journal of Second Language Writing, 30, 66-81.

Mahfoodh, OHA. (2017). "I feel disappointed": EFL university students' emotional responses towards teacher written feedback. Assessing Writing, 31, 53-72.

Marefat, F, \& Heydari, M. (2016). Native and Iranian teachers' perceptions and evaluation of Iranian students' English essays. Assessing Writing, 27, 24-36.

McMartin-Miller, C. (2014). How much feedback is enough? : instructor practices and student attitudes toward error treatment in second language writing. Assessing Writing, 19, 24-35.

Montgomery, JL, \& Baker, W. (2007). Teacher-written feedback: student perceptions, teacher self-assessment, and actual teacher performance. Journal of Second Language Writing, 16, 82-99.

Murphy, S. (2000). A sociocultural perspective on teacher response: is there a student in the room? Assessing Writing, $7,79-90$

Nakata, Y. (2010). Improving the classroom language proficiency of non-native teachers of English: what and how? RELC Journal, 41(1), 76-90.

Nassaji, H. (2012). The relationship between SLA research and language pedagogy: teachers' perspectives. Lanquage Teaching Research, 16(3), 337-365.

Nemati, M, Alavi, SM, Mohebbi, H, Panahi Masjedlou, A. (2017). Speaking out on behalf of the voiceless learners: written corrective feedback for English language learners in Iran. Issue in Educational Research, 27(4), 822-841.

Richards, JC. (2017). Introduction. RELC Journal, 48(1), 3-5.

Shin, SJ. (2006). Learning to teach writing through tutoring and journal writing. Teachers and Teaching, 12(3), 325-345.

Tavakoli, P. (2015). Connecting research and practice in TESOL: a community of practice perspective. RELC Journal, $46(1), 37-52$.

Tavakoli, P, \& Howard, MJ. (2012). Teaching English to speakers of other languages teachers' views on the relationship between research and practice. European Journal of Teacher Education, 35(2), 229-242.

Truscott, J. (1996). The case against grammar correction in L2 writing classes. Language Learning, 46(2), 327-369.

Truscott, J. (1999). The case for "the case against grammar correction in L2 writing classes": a response to Ferris. Journal of Second Language Writing, 8(2), 111-122.

Truscott, J. (2001). Selecting errors for selective error correction. Concentric: Studies in English Literature and Linguistics, $27(2), 93-108$

Truscott, J. (2004). Evidence and conjecture on the effects of correction: a response to Chandler. Journal of Second Language Writing, 13, 337-343.

Truscott, J. (2007). The effect of error correction on learners' ability to write accurately. Journal of Second Language Writing, 16, 255-272

Truscott, J. (2009). Arguments and appearances: a response to Chandler. Journal of Second Language Writing, 18, 59-60.

Truscott, J. (2010). Some thoughts on Anthony Bruton's critique of the correction debate. System, 38, 329-335.

Tsang, A. (2017). EFL/ESL teachers' general language proficiency and learners' engagement. RELC Journal, 48(1), 99-113.

Valmori, L, \& De Costa, PI. (2016). How do foreign language teachers maintain their proficiency? A grounded theory investigation. System, 57, 98-108.

Weigle, SC. (2007). Teaching writing teachers about assessment. Journal of Second Language Writing, 16, 194-209.

Zhou, AA, Busch, M, Cumming, A. (2014). Do adult ESL learners' and their teachers' goals for improving grammar in writing correspond? Language Awareness, 23(3), 234-254.

\section{Submit your manuscript to a SpringerOpen ${ }^{\circ}$} journal and benefit from:

- Convenient online submission

- Rigorous peer review

Open access: articles freely available online

- High visibility within the field

- Retaining the copyright to your article

Submit your next manuscript at $\gg$ springeropen.com 